\title{
The Impact of Instructing Quadratic Functions with the Use of Geogebra Software on Students' Achievement and Level of Reaching Acquisitions
}

\author{
Filiz Tuba Dikkartin Övez ${ }^{1}$ \\ ${ }^{1}$ Balikesir University, Necatibey Faculty of Education, Department of Mathematics Education Balıkesir, Turkey \\ Correspondence: Filiz Tuba Dikkartın Övez, Balikesir University, Necatibey Faculty of Education, Department of \\ Mathematics Education, Balıkesir, Turkey. Tel: 90-50-5378-5192. E-mail: tdikkartin@balikesir. edu.tr
}

Received: March 9, 2018

Accepted: April 10, 2018

Online Published: June 28, 2018

doi:10.5539/ies.v11n7p1

URL: https://doi.org/10.5539/ies.v11n7p1

\begin{abstract}
The objective of this study is to examine the impact of instructing quadratic functions with the use of GeoGebra software and guided discovery worksheets on students' achievement and level of reaching acquisitions. This study utilized a pretest-posttest control group experimental design. It was conducted in the 2017-2018 academic year with 62 tenth grade students of a high school in the center of Balikesir, Turkey. The study data was collected using quadratic functions achievement test. The quantitative data collected in the study were analyzed using independent samples t-test. The findings of the study indicated that the instruction exercised with the use of GeoGebra software and guided discovery worksheets was effective in increasing achievement and the level of the capability to reach acquisitions compared to the control group; the findings also indicated that the instruction created a significant difference. This study also found that the students in the control group students focused on algebraic operations and formulas, mainly memorized the formulas, and were unable to build the relation between graphics and the algebraic expression of functions. On the other hand, the students in the experimental group were better in building the relation between algebraic expressions and graphics, and more successful in interpreting graphics.
\end{abstract}

Keywords: geogebra, quadratic functions, level of reaching acquisitions, student achievement

\section{Introduction}

Learning and instructing mathematics are highly complex processes. In general, the cognitive complexity of mathematics reflects the nature of learning and instructing mathematics, which can be characterized in multiple dimensions. Learning mathematics is both an individual and a social process; each mathematical concept is connected with other concepts. This structure among mathematical concepts is similar to a complicated web network due to multiple displays, different representations, and the connections between them (Freudenthal, 1973; Gutiérrez \& Boero, 2006; Lesh \& Doerr, 2003). For instance; a parabola can be understood looking at its relations with lines, conics, dots, squares, surface area, free fall, and other similar aspects. Additionally, it is also represented by numeric, algebraic, and geometric displays and the connections of these displays. In the end, mathematical displays are cultural artworks that show the cultural and technological developments of a particular society (Kaput, Hegedus, \& Lesh, 2007; Presmeg, 2006). While this structure of mathematics has affected the development of technology, the development of technology has changed the understanding of mathematics instruction.

For a long time, the instruction of mathematics from primary school to university has adopted non-interactive teaching methods which assign students the role of receivers from the teacher (Abdulwahed, Jaworski \& Crawford, 2012). However, this understanding has changed due to both the rapid change in technology and the start of using innovation technologies in teaching environments. In this respect, there have been many reformist movements that aim to integrate more innovative pedagogic approaches, which are generally based on the constructivist theory, into the teaching environment with the purpose of supporting students' theoretical understanding (Abate \& Cantone, 2005; Chang, 2011) Furthermore, technology is regarded as the activator of innovative mathematics education, and it is defended that the development of technology leads to a reform in learning and teaching mathematics (Chang, 2011; Roddick, 2001). For instance, the start of using dynamic software such as Matlab, LabView, and Cabri 3D in mathematics instruction has led to the design of teaching environments based on the constructive approach with the aim of encouraging research, developing projects, 
modeling, and facilitating conceptual understanding in mathematics lessons (Abdulwahed, Jaworski, \& Crawford, 2012; Jaworski, 2010). Similarly, GeoGebra, one of the 21st-century-inventions, has become one of the few new generation mathematics learning technologies that reshape the representative background of mathematics instruction, and enable the easy and free access of the worldwide community to mathematical processes and tools (Kaput et al., 2007).

It has been suggested that the teaching programs, having been renovated within this growing approach, use new technologies for teaching, offer meaningful activities to students, and give students the opportunity to discuss and share knowledge in a social environment (National Council of Teachers of Mathematics, 2000; Ministry of National Education, 2017; International Educational Technology Standards for Teachers, 2008). In the present day when the use of technology has rapidly entered in all areas, benefiting from technology in mathematics instruction will ensure the new generation (called "digital natives") to gain a positive attitude towards mathematics, and improve the productivity and permanency of education and training (Kutluca \& Birgin, 2007; Orton \& Roper, 2000). Moreover the use of computers to explore, discover, and obtain mathematical concepts and relations will change the traditional environment of teaching and learning mathematics and will help them a lot in giving meanings to mathematical concepts (Papert, 1980). It is known that the concepts which students fail to learn lead misunderstandings, and create obstacles before the perception of the concepts that would be learned later (Sotos, Vanhoof, Van den Noortgate, \& Onghena, 2007).

Thus, according to the standards of National Council of Teachers of Mathematics, teaching methods of various mathematical subjects such as functions, graphs, limit, derivative, and integral must be changed depending on contemporary approaches (NCTM 2000). In this respect, dynamic mathematical software serve for the instruction of mathematics subjects and carry the potential to realize the expected change thanks to the opportunities they provide for the examination of the geometric representations of mathematical concepts (Edwards and Jones, 2006). Various research results have demonstrated that dynamic geometry software is a powerful technological tool in teaching mathematics. In addition, these softwares can be used to encourage discovery and experimentation in classrooms, and visualization skills can be used effectively in teaching presuppositions (Bu, Spector, \& Haciomeroglu, 2011; Dos Santos \& Trocado, 2016; Hohenwarter, Hohenwarter, Kreis, \& Lavicza 2008).

GoeGebra is one of the dynamic mathematics software which is the combination of both geometric and algebraic constructions. It reinforces students to discover mathematical concepts by doing practice For teachers, GeoGebra offers the powerful opportunity to create interactive online learning environments. Geogebra is to join geometry, algebra, and calculus into a single easy-to-use package for learning and teaching mathematics from elementary through university level (Hohenwarter and Fuchs, 2004). Designed specifically for educational purposes, GeoGebra can help students grasp experimental, problem-oriented and research-oriented learning of mathematics, both in the classroom and at home. Students can simultaneously use a computer algebra system and an interactive geometric system; For increase students' cognitive abilities geogebra applications can be used by teachers. Because GeoGebra encourages students'experimental and guided discovery learning. In addition, GeoGebra is a program that enables use without training students about the software thanks to its dynamic worksheet quality. GeoGebra, a tool that has active utilization areas in mathematics teaching and learning activities, is benefited in order to develop interactive and creative visual implementations in algebra and geometry subjects by means of dynamic worksheets (Aktümen \& Kabaca, 2012; Baydas, Göktas, \& Tatar, 2013).

The results of the previous studies demonstrated that GeoGebra software facilitates the recognition of the relations between mathematical structures by contributing to the process of discovering mathematics, and enables students to grow positive attitudes by making the teaching and learning process more enjoyable (Ardiç \& Isleyen 2017; Dockendorff \& Solar, 2018; Kutluca \& Baki, 2009). Considering the opportunities GeoGebra provides, the researcher believes that the teaching environments to be prepared with the use of this software will be functional in many mathematics subjects with which students have difficulty. Studies on the difficulty levels of the subjects in the $9^{\text {th }}-12^{\text {th }}$ grade mathematics curricula revealed that half of the subjects were qualified to be difficult (difficulty index: 30 or above) by the students (Durmuş, 2004; Kutluca \& Baki, 2009; Tatar, Okur, \& Tuna, 2008). Function is one of these subjects. It is a fundamental concept that is central to the high school and university mathematics curricula. For this reason, the understanding of a large number of subjects in mathematics where prerequisite relations are important depends on the accurate establishment of function concept in mind (Even, 1993; Sajka, 2003). Even though function is one of the fundamental subjects of mathematics, most students understand this subject inaccurately and have difficulty in learning it (Ural, 2006).

The most common mistakes made by students are listed briefly below:

- Considering a function as an equation and unknown, and trying to solve it 
- Accepting the function as a formula

- Accepting the function as a process of operation

- Accepting the function as a type of formula that is used for drawing graphics

- Having trouble in solving and interpreting the graphic due to accepting the function's graphic as a fixed object

- Believing that a function can be described with only one algebraic formula, and failing to understand piecewise functions

- $\quad$ Failing to build the relation between function's equation and graphic (Breidenbach, Dubinsky, Hawks, \& Nichols, 1992; Carlson \& Oehrtman, 2005; Monk, 1992; Sierpinska, 1992; Vinner \& Dreyfus, 1989).

The difficulties that students have in the subject of function and its graphics result in a low level of reaching relevant acquisitions in the $9^{\text {th }}-12^{\text {th }}$ grade mathematics curricula. A study conducted by Övez-Dikkartın (2012) found that students reached only $25 \%$ of the acquisitions in ninth grade 'Relation, Function, and Operation' unit, while they reached none of the acquisitions in the tenth grade 'Quadratic Functions' sub-area of learning. With a consideration of these results, researchers believe that it is important to instruct quadratic functions in teaching environments that are enriched with new and contemporary materials, and examine their effects on students' achievement. In this context, this study aimed to examine the effects on students' achievement of using GeoGebra software in the instruction of quadratic functions, which is commonly known to be problematic to teach. This software is widely accepted to be advantageous in that it is in Turkish and easy to use, provides common utilization in many different subjects of mathematics, and it is constructed on the thinking of enabling the analysis of relationships between the different representations. Accordingly, the objective of this study is to examine the impact of instructing quadratic functions with the use of GeoGebra software and guided discovery worksheets on students' achievement and level of reaching acquisitions. With this objective, the study attempted to solve the research problems below:

Research problems

- Is there any significant difference between the achievement scores on 'quadratic functions' sub-area of learning obtained by the experimental group that was taught using GeoGebra software and guided discovery worksheets and the control group that did not receive this type of instruction?

- What are the levels of reaching quadratic functions sub-area of learning acquisitions for experimental and control groups?

\section{Method}

In this part, information about the research model, choosing the participants, data collection and data analysis and process is provided.

\subsection{Research Model}

In this study experimental pattern with pre-test and post-test control group was used. According to model, two groups -one is test the other one is control - were composed with an unbiased assignment (random) method. An experimental research method was used in this study. An experimental study aims to determine the causality relationships between variables by examining any event, phenomenon, object, subject, and factor, and make a comparison and measurement of the results of these relationships (Karasar, 2008). The model of this study was derived from the "pretest-posttest control group design" of the experimental method. In context of the study, there was no intervention into the text books and exercises in the current curriculum of the control group students while the students in the experimental group students were taught using GeoGebra exercises that were developed in the computer laboratory in addition to guided discovery worksheets.

\subsection{Participants}

This study was conducted in the 2017-2018 academic year with 62 tenth grade students of a high school in the center of Balikesir, Turkey. The reason for selecting this school for the study was that they had the suitable computer laboratory equipment for doing the implementation. Test and control group students were assigned unbiasedly (randomly) according to the report card scores of the ninth-grade (class) in mathematics course and the pre-test score averages so the formation of two equivalent groups was aimed.

\subsection{Data Collection Tools}

An achievement test of Quadratic Functions was used as a data collection tool in the study. The tests given to the students at the beginning and at the end of the study as a pre-test and posttest were developed in a multiple choice 
type of test. The achievement test was composed of four items, each of which took the form of a question to measure each acquisition in sub-learning field of quadratic functions.

An item pool of 16 questions was arranged to mainly measure the acquisitions while the test is being developed. Then, the proposed test was submitted to field experts for their consideration and received their opinions in terms of clarity, relevance of the questions and their compliance with the acquisitions. Their opinions regarding the test items were utilized so content validity ratios (CVR) of the items were determined and at $\alpha=0.05$ significance level the minimum level of CVR as 0.78 (Veneziano \& Hooper, 1997) and above it was accepted as significant. These items were included in pre-trial test and a pre-trial test consisting of three questions to measure each acquisition was then constituted. The pre-trial test was applied to 197 eleventh-grade students that were randomly-selected from two secondary education schools. Obtained results were then subjected to item analysis. One question measuring in the best manner each of 4 acquisitions, whose ttem discriminatory power index is greater than .30 was selected by considering the ones with the greatest item discriminatory power and the test was given its final form. Validity coefficient of this test was found as (KR920) 0.89 .

\subsection{Process}

In experimental group, as a first group of activities; discovery sheets were given to students to discover the properties of functions. In application of discovery sheets, students filled in the blanks in each question which is designed to help students to be discovered properties. The discovery sheets required individual work of students with geogebra software. The achievement test that was created in this study was applied as a pretest and a posttest before and after the implementation. Then, exercises and worksheets were organized using GeoGebra software for the instruction of 'quadratic functions' subject. The instruction of the subject to the control group students using text book and available materials within the context of tenth-grade curriculum was performed by the researcher. The content of worksheets prepared in line with the expert view is as follows. The first worksheet consisted of the applications where the student calculated the highest and lowest value of the function by using the quadratic function equation. In the second worksheet the question of circus acrobat that was given as an example of activity in the program was asked (MNE, 2007).

"The orbit (trajectory) of circus acrobat thrown by a ball is given with the graph of

$$
f(x)=x-x^{2} / 100
$$

function. Both the ball and the stretched net are 10-meter high from the ground. In order to allow the circus acrobat to fall down in the middle of the net find out the distance between the edge (mouth) of the ball and the middle point of the net and find out how many meters in maximum the circus acrobat soared high."

Students were requested to draw the graph of the function in the problem within GeoGebra coordinate system and to conduct necessary measurements. Similarly, different parabole (parabola) equations were given to them and students were made aware of the graph's (parabole) peak point of a quadratic function and the points cutting axes. In the third worksheet students were helped to find the symmetry axis of parabole by using reflection (symmetry) button of GeoGebra and various applications were conducted. In the next three worksheets applications prepared depending on guided discovery principle regarding the graph and the leading coefficient of quadratic function equation were conducted. In another worksheet applications regarding the change in peak point with the assistance of a bar were performed (Figure 1, Figure 2, Appendix A). 


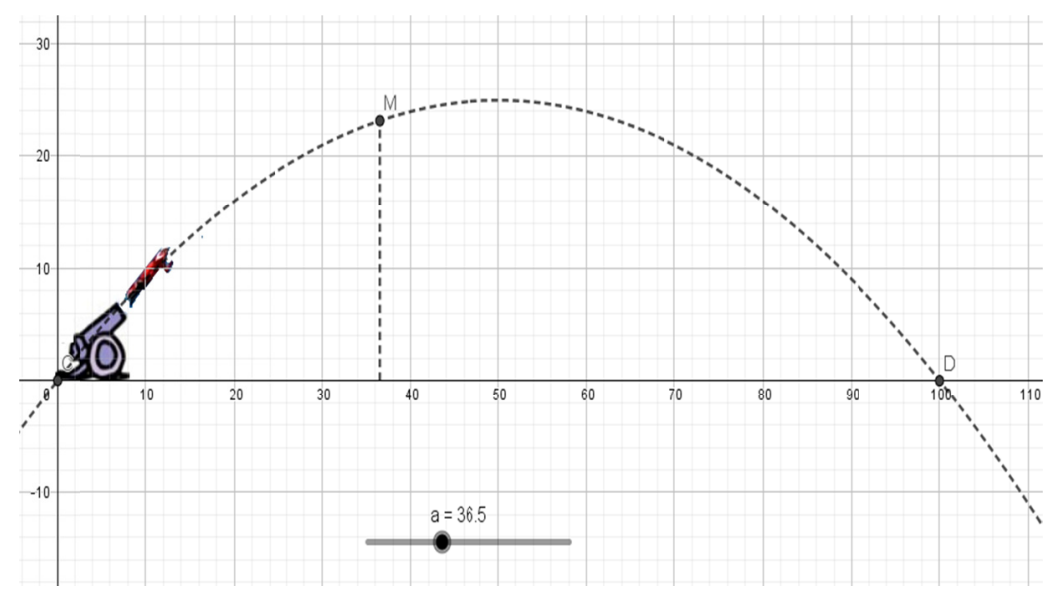

Figure 1. Activity examples

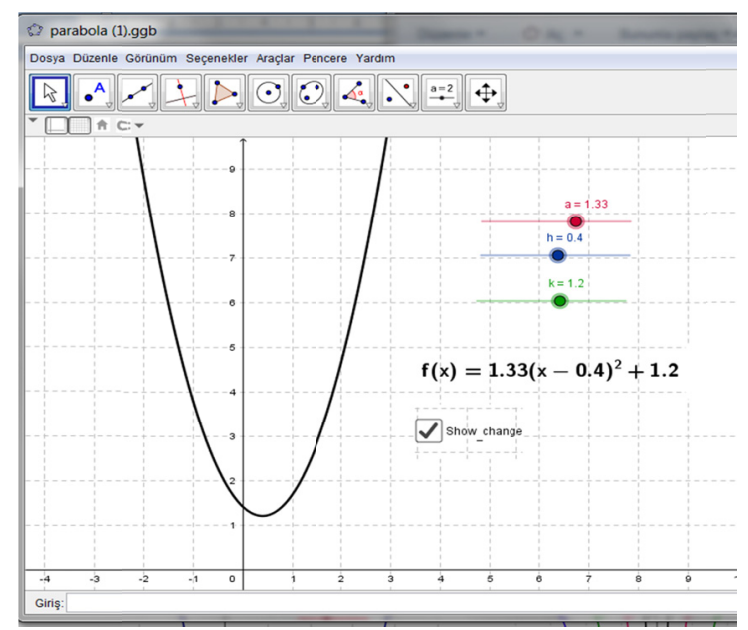

Figure 2. Activity examples

Applications such as finding out a quadratic function whose any three points are given, indicating the solution set of inequality with two unknowns and the inequality system over a graph were conducted. In addition, activities on when a parabole will be tangent to axes or the tangent equation cutting the peak point were performed (Figure 2).

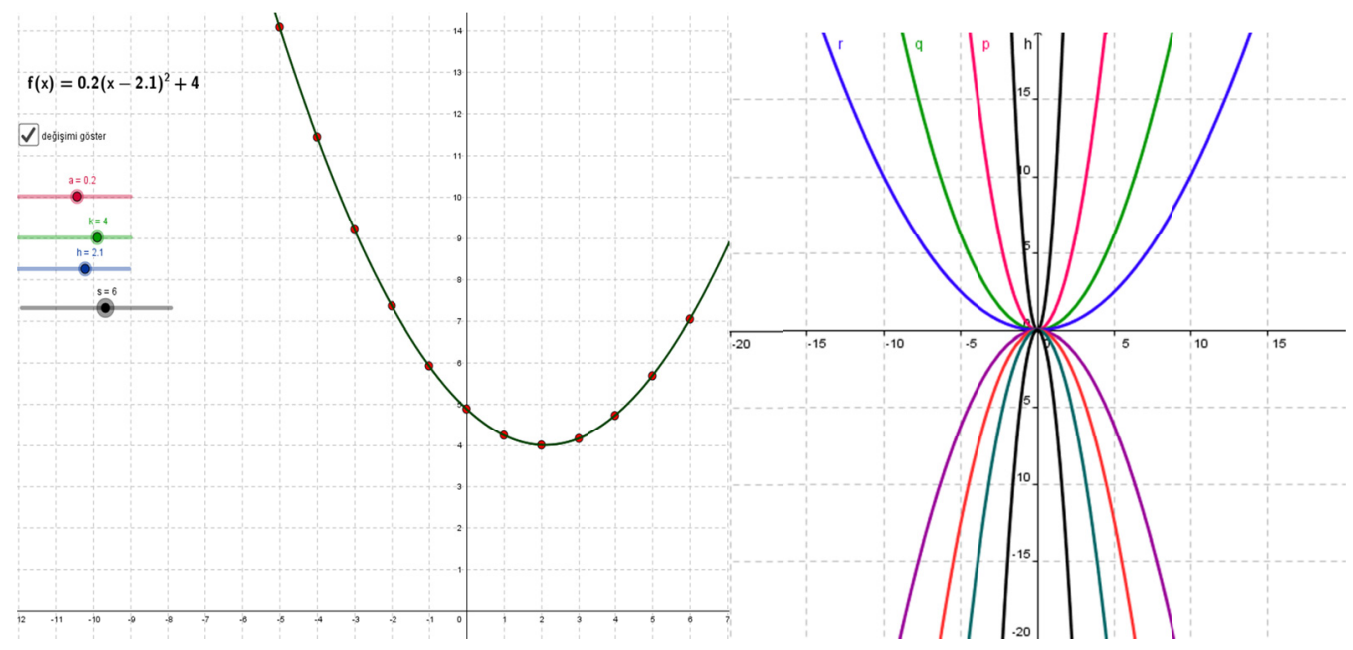

Figure 3. Activity examples 


\section{Findings and Interpretation}

\subsection{The Findings Related to the First Research Problem}

The first research problem of this study was "Is there any significant difference between the achievement scores on 'quadratic functions' sub-area of learning obtained by the experimental group that was taught using GeoGebra software and guided discovery worksheets and the control group that did not receive this type of instruction?". With this objective, the achievement levels for experimental and control groups were compared using independent samples $t$ test. The difference between the groups' mean scores on the pretest and the posttest was accepted as the achievement score. Table 1 presents the study findings.

Table 1. Comparison on achievement scores of test and control groups

\begin{tabular}{ccccccc}
\hline Group & $\mathrm{N}$ & $\overline{\mathrm{X}}$ & $\mathrm{S}$ & $\mathrm{Sd}$ & $\mathrm{t}$ & $\mathrm{p}$ \\
\hline Control & 31 & 1.48 & 1.31 & & & \\
Test & 31 & 3.06 & 0.85 & & $-5,618$ & $.001^{*}$ \\
\hline
\end{tabular}

$* \mathrm{p}<0.05$

When Table 1 is reviewed, it is seen that achievement test score averages as the difference between pre-test $(\bar{x}=0.41)$ and post-test $(\bar{x}=3.06)$ score averages of the test group was 2.65 and that achievement score averages as the difference between pre-test $(\bar{x}=0.38)$ and post-test $(\bar{x}=1.48)$ score averages of the control group was 1.1. There is an average difference in favor of the test group between the average achievement scores of Test and Control Groups. According to " $\mathrm{t}$ " test results, it was observed that there was a significant difference between achievement score averages $[\mathrm{t}=-5.61 ; \mathrm{p}=.001<.05]$. This finding indicates that for students' achievement level computer -aided education applied in test group was more effective than the technique of text book, paper, and pencil used in the control group. The results of many studies in literature also support this finding (Skryabin, Zhang, Liu, \& Zhang, 2015; Gutiérrez \& Prieto, 2015; Zengin \& Tatar, 2017).

\subsection{The Findings Related to the Second Research Problem}

It is the question of "What are the attainment levels of Test and Control groups for the acquisitions of sub-learning field of quadratic functions? To this end, item difficulty index $\left(\mathrm{p}_{\mathrm{j}}\right)$ values obtained from pre-test and post-test results of test and control group students and the calculated results showing the differences between them are given in Table 2.

Table 2. Test and control groups' attainment levels for the acquisitions of algebra learning field

\begin{tabular}{|c|c|c|c|c|c|c|c|}
\hline & \multirow[b]{2}{*}{ Acquisitions(A) } & \multicolumn{3}{|c|}{ Control } & \multicolumn{3}{|c|}{ Test } \\
\hline & & $\begin{array}{c}\text { Pre-Test } \\
\left(\mathrm{P}_{\mathrm{j}}\right)\end{array}$ & $\begin{array}{c}\text { Post-Test } \\
\left(\mathrm{P}_{\mathrm{j}}\right)\end{array}$ & $\mathrm{t}$ & $\begin{array}{c}\text { Pre-Test } \\
\left(\mathrm{P}_{\mathrm{j}}\right)\end{array}$ & $\begin{array}{c}\text { Post-Test } \\
\left(\mathrm{P}_{\mathrm{j}}\right)\end{array}$ & $\mathrm{t}$ \\
\hline \multirow{4}{*}{ 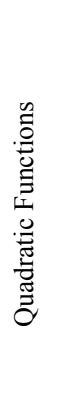 } & $\begin{array}{l}\text { A1. They explain a quadratic function and calculate its highest } \\
\text { or lowest value. }\end{array}$ & .00 & .48 & $-5.30^{*}$ & .00 & .77 & $-10.14 *$ \\
\hline & $\begin{array}{l}\text { A2. They discover the peak point of a graph (Parabole) of a } \\
\text { quadratic function and the points cutting the axes, and } \\
\text { symmetry axis. They arrange the conversion table of the } \\
\text { function and draw its graph. }\end{array}$ & .06 & .25 & $-2.68 *$ & .38 & .80 & $-3.47 *$ \\
\hline & $\begin{array}{l}\text { A3. They discover a quadratic function, whose peak point, any } \\
\text { of its points, or any three points are given over its graph. }\end{array}$ & .32 & .61 & $-3.50 *$ & .00 & .78 & $-10.14 *$ \\
\hline & $\begin{array}{l}\text { A4. They show the solution set of inequality of two unknowns } \\
\text { and inequality system over the graph. }\end{array}$ & .00 & .12 & $-2.10^{*}$ & .03 & .70 & $-7.93 *$ \\
\hline
\end{tabular}
$* \mathrm{p}<0.05$.

When Table 2 was reviewed, at the beginning of education process it was seen that test and control group students were able to acquire none of the acquisitions at the level of .75 according to pre-test results. When the post-test results were reviewed, it was determined that control group students were able to acquire none of the acquisitions but test group students acquired the acquisitions measured by the items numbered 1,2, and 3 . This finding that was obtained shows parallelism with the results of the study performed by Övez-Dikkartın (2012). It was observed that 
none of the acquisitions stated in the study performed over algebra learning field regarding program evaluation, were acquired at the level of .75. Contrary to this, as a result of education with the use of GeoGebra and guided discovery worksheet it was seen that the achievement of test group in comparison with that of control group was fairly good; however, it was specified that both groups were not able to acquire the acquisition measured by the fourth item. The reason for this is that students may not have acquired some acquisitions in the sub learning field of Quadratic Equations and Inequalities. Also the results of the study done by Övez-Dikkartın (2012) are capable of supporting this idea. In this connection, it is considered that students' lack of knowledge in maths course where prerequisite relations are important affects the achievement.

\section{Result and Discussion}

The study concluded that the instruction which used GeoGebra activities was more successful in increasing achievement and in the level of reaching acquisitions compared to the instruction performed in framework of the current tenth grade curriculum.

In the study during the control group applications it was seen that the students usually laid stress on algebraic operations and formulas and that they mostly memorized them and that they could not establish a relation between the graphs and algebraic expression of function. The results of the study performed by Even (1990) also support this situation. According to Even (1990), one of the important matters in interpreting the graphs is quadratic function itself. If students understand the relation between parameter " $a$ " in the expression of $a^{2}+b x+c$ and the quadratic function, and its graph, then they may be capable of generalizing the relation between the leading coefficient, function and its graph. Therefore it is necessary to understand very well both graph demonstration of a quadratic equation and the role of parameter " $\mathrm{a}$ " in the expression of $\mathrm{ax}^{2}+\mathrm{bx}+\mathrm{c}$ in its symbolic demonstration. Memorizing the formula is not adequate alone (Even, 1990).

Test group students were able to establish the relation between the algebraic expression and the graphs better and that they became more successful in interpreting them. The reason is that students may have revealed existing relations by way of guided discovery and that they may have constituted their own examples by using GeoGebra program.

Moreover as GeoGebra was in Turkish, students used this program more easily. It also provides many advantages in drawing function graphs. GeoGebra is able to represent functions in the forms: formula, graph, and numerical table, simultaneously. This capability helps the students analyze the effect of parameter changes on the graph of functions. This application also helps the students focus on the qualitative analysis, instead of complicated calculations (Darmawan \& Pranoto, 2011)

As a result of the implementation, the study provided a learning environment that was stronger in visual terms thanks to GeoGebra activities, and the students could reach informal generalizations by witnessing the effect of large numerical data on graphics. In this regard, the study found that $75 \%$ of the experimental group students reached the pre-determined acquisitions, while this rate was $0 \%$ for the control group. This study used the dynamic mathematics software GeoGebra to visualize the concepts related to quadratic functions which students have difficulty about with an inclusion of dynamic elements. This study also developed materials addressing to the creation of the dynamic environment accompanied by guided discovery questions and examined their impact on the achievement. The implementation performed in this study gave students the opportunity for reasoning, making discoveries, generalizing, and proving. Therefore, students found the chance to form their own knowledge based on personal experiences. The results obtained in the study demonstrated that using GeoGebra practices in the instruction of quadratic functions which requires reading, creating, and interpreting graphics was effective in increasing achievement and reaching acquisitions. Accordingly, this study recommends that future studies should benefit from the effects of GeoGebra, which combines computer algebra systems and dynamic geometry software, and other dynamic software for various subjects which are known to involve difficulties in being understood by students. It is also recommended that a variety of studies should be conducted on the integration of technology into mathematics instruction with the objective of examining GeoGebra software's effect on students' knowledge formation process. Exemplary practices that were developed to see these effects can act as a guide for teachers regarding the type of teaching environment that should be designed for the integration of digital materials into the education and training environment.

\section{References}

Abate, C. J., \& Cantone, K. (2005). An evolutionary approach to mathematics education: enhancing learning through contextual modification. Primus, 15(2), 157-176. https://doi.org/10.1080/10511970508984115

Abdulwahed, M., Jaworsk1, B., \& Crawford, A., (2012). Innovative approaches to teaching mathematics in 
higher education: a review and critique. Nordic Studies in Mathematics Education, 17(2), 49-68. Retrieved from https://dspace.lboro.ac.uk/dspace-jspui/handle/2134/11988

Aktümen, M., \& Kabaca, T. (2012). Exploring the mathematical model of the thumbaround motion by Geogebra. Technology, Knowledge and Learning, 17(3), 109-114. https://doi.org/10.1007/s10758-012-9194-5

Ardiç, M. A., \& Isleyen, T. (2017). Secondary School Mathematics Teachers' and Students' Views on Computer Assisted Mathematics Instruction in Turkey: Mathematica Example. Malaysian Online Journal of Educational Technology, 5(1), 46-64. Retrieved from https://files.eric.ed.gov/fulltext/EJ1125131.pdf

Baki, A., \& Kutluca, T., (2009). Dokuzuncu sınıf matematik programında zorluk çekilen konuların konuların belirlenmesi. e-Journal of New World Sciences Academy, 4(2), 604-619. Retrieved from http://dergipark.gov.tr/download/article-file/185957

Baydas, Ö., Göktas, Y., \& Tatar, E. (2013). The use of GeoGebra with different perspectives in mathematics teaching. Çukurova University Faculty of Education Journal, 42(2), 36. Retrieved from http://dergipark.ulakbim.gov.tr/cuefd/article/view/1054000049/cufej.2013.015

Breidenbach, D., Dubinsky, E. D., Hawks, J., \& Nichols, D. (1992). Development of the process conception of function. Educational Studies in Mathematics, 23(3), 247-285. https://doi.org/10.1007/BF02309532

$\mathrm{Bu}, \mathrm{L} .$, Spector, J. M., \& Haciomeroglu, E. S. (20 11). Toward model-centered mathematics learning and instruction using GeoGebra: A theoretical framework for learning mathematics with understanding. In L. $\mathrm{Bu}, \&$ R. Schoen (Eds.), Model-centered learning: Pathways to mathematical understanding using GeoGebra (pp. 13-40). Rotterdam, The Netherlands: Sense Publishers.

Carlson, M. P., Oehrtman, M. C., \& Thompson, P. W. (2005). Key aspects of knowing and learning the concept of function. In M. P. Carlson, \& C. Rasmussen (Eds.), Making the connection: Research and practice in undergraduate mathematics. Washington, DC: Mathematical Association of America.

Chang, J. M. (2011). A practical approach to inquiry-based learning in linear algebra. International Journal of Mathematical Education in Science and Technology, 42(2), 245-259. https://doi.org/10.1080/0020739X.2010.519795

Darmawan, \& Pranoto, I. (2011). On The teaching of analyzing the effects of parameter changes on the graph of function. International Seminar and the Fourth National Conference on Mathematics Education, Yogyakarta.

Dockendorff, M., \& Solar, H. (2018). ICT integration in mathematics initial teacher training and its impact on visualization: the case of GeoGebra. International Journal of Mathematical Education in Science and Technology, 49(1), 66-84. https://doi.org/10.1080/0020739X.2017.1341060

Dos Santos, J. M. D. S., \& Trocado, A. E. B. (2016). GeoGebra as a Learning Mathematical Environment. Revista do Instituto GeoGebra Internacional de São Paulo, 5(1), 05-22. Retrieved from https://revistas.pucsp.br/index.php/IGISP/article/view/26795/19963

Durmuş, S. (2004). A study to determıne learnıng difficultıes in secondary mathematıcs education. Kastamonu Education Journal, 12(1), 125-128. Retrieved from http://www.kefdergi.com/pdf/16_2/507-516.pdf

Edwards, J. A., \& Jones, K. (2006). Linking Geometry and Algebra with Geogebra. Mathematics Teaching, 194, 28-30. Retrieved from https://eprints.soton.ac.uk/19198/1/Edwards_Jones_linking_geometry_and _algebra_MT_2006.pdf

Even, R. (1990). Subject matter knowledge for teaching and the case of functions. Educational Studies in Mathematics, 21(6), 521-544. https://doi.org/10.1007/BF00315943

Even, R. (1993). Subject-matter knowledge and pedagogical content knowledge: prospective secondary teachers and the function concept. Journal for Research in Mathematics Education, 24(2), 94-116. https://doi.org/10.2307/749215

Freudenthal, H. (1973). Mathematics as an Educational Task, D. Reidel, Dordrecht. Springer Science \& Business Media.

Gutiérrez, Á., \& Boero, P. (2006). Handbook of research on the psychology of mathematics education: Past, present and future. Rotterdam, Holanda: Sense Publishers

Gutiérrez, R. E., \& Prieto, J. L. (2015). Deformación y reflexión de funciones con GeoGebra. El caso de las parábolas definidas por la expresión $\mathrm{g}(\mathrm{x})=\mathrm{a} \cdot \mathrm{x}^{\wedge} 2$. Números. Revista de Didáctica de las Matemáticas, 88 , 115-126. Retrieved from http://funes.uniandes.edu.co/6578/1/Mundogeogebra.pdf 
Hohenwarter, M., \& Fuchs, K. (2004). Combination of dynamic geometry, Algebra and Calculus in the software system GeoGebra. Computer Algebra Systems and Dynamic Geometry Systems in Mathematics Teaching Conference. Pecs, Hungary. Retrieved from https://archive.geogebra.org/static/publications/pecs_2004.pdf

Hohenwarter, M., Hohenwarter, J., Kreis, Y., \& Lavicza, Z. (2008). Teaching and learning calculus with free dynamic mathematics software GeoGebra. 11th International Congress on Mathematical Education. Monterrey, Nuevo Leon, Mexico. https://pdfs.semanticscholar.org/1c8c/9f4765c2ad5080b59b08e3b 77b036e780a5f.pdf

Hohenwarter, M., Preiner, J., \& Yi, T. (2007). Incorporating GeoGebra into teaching mathematics at the college level. Proceedings of the International Conference for Technology in Collegiate Mathematics 2007. Boston, USA: ICTCM Retrieved from http://archives.math.utk.edu/ICTCM/VOL19/S100/paper.pdf

International Educational Technology Standards for Teachers (ISTE). (2008). Review from http://www.iste.org/Content/NavigationMenu/NETS/ForTeachers/2008Standards/NETS_T_Standards_Final .pdf

Jaworski, B. (2010). Challenge and support in undergraduate mathematics for engineers in a GeoGebra medium. MSOR Connections, 10(1), 10-14. https://doi.org/10.11120/msor.2010.10010010

Kaput, J., Hegedus, S., \& Lesh, R. (2007). Technology becoming infrastructural in mathematics education. In R. A. Lesh, E. Hamilton. \& J. J. Kaput (Eds.), Foundations for the future mathematics education (pp. 170-191). Mahwah, NJ: Lawrence Erlbaum Associates

Karasar, N. (2008). Bilimsel araştırma yöntemi: kavramlar-ilkeler-teknikler. Nobel Yayın Dağitim.

Kutluca, T., \& Birgin, O. (2007). Doğru denklemini konusunda geliştirilen bilgisayar destekli öğretim materyali hakkında matematik öğretmenlerinin görüşlerinin değerlendirilmesi. Gazi Eğitim Fakültesi Dergisi, 27(2), 81-97. Retrieved from http://www.gefad.gazi.edu.tr/download/article-file/77167

Kutluca, T., \& Baki, A. (2009). 10. Sınıf Matematik Dersinde Zorlanılan Konular Hakkında Öğrencilerin, Öğretmen Adaylarının ve Öğretmenlerin Görüşlerinin İncelenmesi. Kastamonu Üniversitesi Kastamonu Eğitim Dergisi, \&, 2, 616-632. Retrieved from http://www.kefdergi.com/pdf/17_2/17_18.pdf

Lesh, R., \& Doerr, H. (2003). Foundations of a models and modeling perspective on mathematics teaching, learning, and problem solving. In R. Lesh, \& H. Doerr (Eds.), Beyond constructivism: Models and modeling perspectives on mathematics problem solving, learning, and teaching (pp. 3-34). Mahwah, NJ: Erlbaum.

Ministry of National Education (MNE). (2007). Ortä̈ğretim 10. Sinıf Matematik Ders Kitabı. Ankara: Talim ve Terbiye Kurulu Başkanlığı.Devlet Kitapları Müdürlüğü.

Ministry of National Education (MNE). (2017). Ortä̈ğretim (9-12) Matematik Dersi Öğretim Programı ve Kılavuzu. Ankara: Devlet Kitapları Müdürlüğü.

Monk, G. S. (1992). Students' understanding of a function given by a physical model. In G. Harel, \& E. Dubinsky (Eds.), The concept of function: Aspects of epistemology and pedagogy (pp. 175-194). Mathematical Association of America, Washington, D.C.

National Council of Teachers of Mathematics. (2000). Principles and Standards for School Mathematics. Reston, VA. NCTM.

Orton, T., \& Roper, T. (2000). Science and mathematics: a relationship in need of counselling? Studies in Science Education, 35(1), 123-153. https://doi.org/10.1080/03057260008560157

Övez-Dikkartın, F. T. (2012), Matematik öğretim programlarının değerlendirilmesi (cebir öğrenme alanı) (Unpublished doctoral dissertation). Balikesir University, Balıkesir, Turkey.

Papert, S. (1980). Mindstorms: Children, computers, and powerful ideas (2nd ed.). New York, NY: Basic Books

Presmeg, N. C. (2006). Research on visualization in learning and teaching mathematics. In A. Gutiérrez \& P. Boero (Eds.), Handbook of research on the psychology of mathematics education (pp. 205-235). Rotterdam: Sense Publishers.

Roddick, C. D. (2001). Differences in learning outcomes: Calculus \& Mathematica vs. traditional calculus. Primus, 11(2), 161-184. Retrieved from https://www.tandfonline.com/doi/pdf/10.1080/10511970108965986?needAccess= true

Sajka, M. (2003). A secondary school students' understandings of the concept of function-A case study. Educational Studies in Mathematics, 53, 229-254. https://doi.org/10.1023/A:1026033415747 
Sierpinska, A. (1992). On understanding the notion of function. In E. Dubinsky, \& G. Harel (Eds.), The Concept of Function: Aspects of Epistemology and Pedagogy, Mathematical Association of America (M.A.A.) Notes, 25, 25-58.

Skryabin, M., Zhang, J., Liu, L., \& Zhang, D. (2015). How the ICT development level and usage influence student achievement in reading, mathematics, and science. Computers \& Education, 85, 49-58. https://doi.org/10.1016/j.compedu.2015.02.004

Sotos, A. E. C., Vanhoof, S., Van den Noortgate, W., \& Onghena, P. (2007). Students' misconceptions of statistical inference: A review of the empirical evidence from research on statistics education. Educational Research Review, 2(2), 98-113. https://doi.org/10.1016/j.edurev.2007.04.001

Tabach, M., \& Nachlieli, T. (2015). Classroom engagement towards using definitions for developing mathematical objects: The case of function. Educational Studies in Mathematics, 90(2), 163-187. https://doi.org/10.1007/s10649-015-9624-0

Tatar, E., Okur, M., \& Tuna, A. (2008). A study to determıne learnıng difficultıes in secondary mathematics education. Kastamonu Education Journal, 16(2), 507-516. Retrieved from http://www.kefdergi.com/pdf/16_2/507-516.pdf

Ural, A. (2006). Fonksiyon öğreniminde kavramsal zorluklar. Aegan Education Journal, 7(2), 75-94. Retrieved from http://dergipark.ulakbim.gov.tr/egeefd/article/view/5000004025/5000004541

Veneziano L., \& Hooper J. (1997). A method for quantifying content validity of health-related questionnaires. American Journal of Health Behavior, 21(1), 67-70.

Vinner, S., \& Dreyfus, T. (1989). Images and definitions for the concept of function. Journal for Research in Mathematics Education, 20, 356-366. https://doi.org/10.2307/749441

Zengin, Y., \& Tatar, E. (2017). Integrating dynamic mathematics software into cooperative learning environments in mathematics. Journal of Educational Technology \& Society, 20(2), 74-88. Retrieved from http://www.jstor.org/stable/pdf/90002165.pdf?refreqid=excelsior\%3A6f31604f21490c9ccf041dc190c186c3

\section{Appendix A}

\section{Angry Birds-(guided discovery worksheet)}

Suzan, who plays the Angry Bird game, is trying to throw four pigs at the target with angry birds. However, Suzan can not achieve the targets with the birds that she threw from point E (0.2). Suzan, realizes that the birds are following a trajectory in the form of parabola. How can we help her.

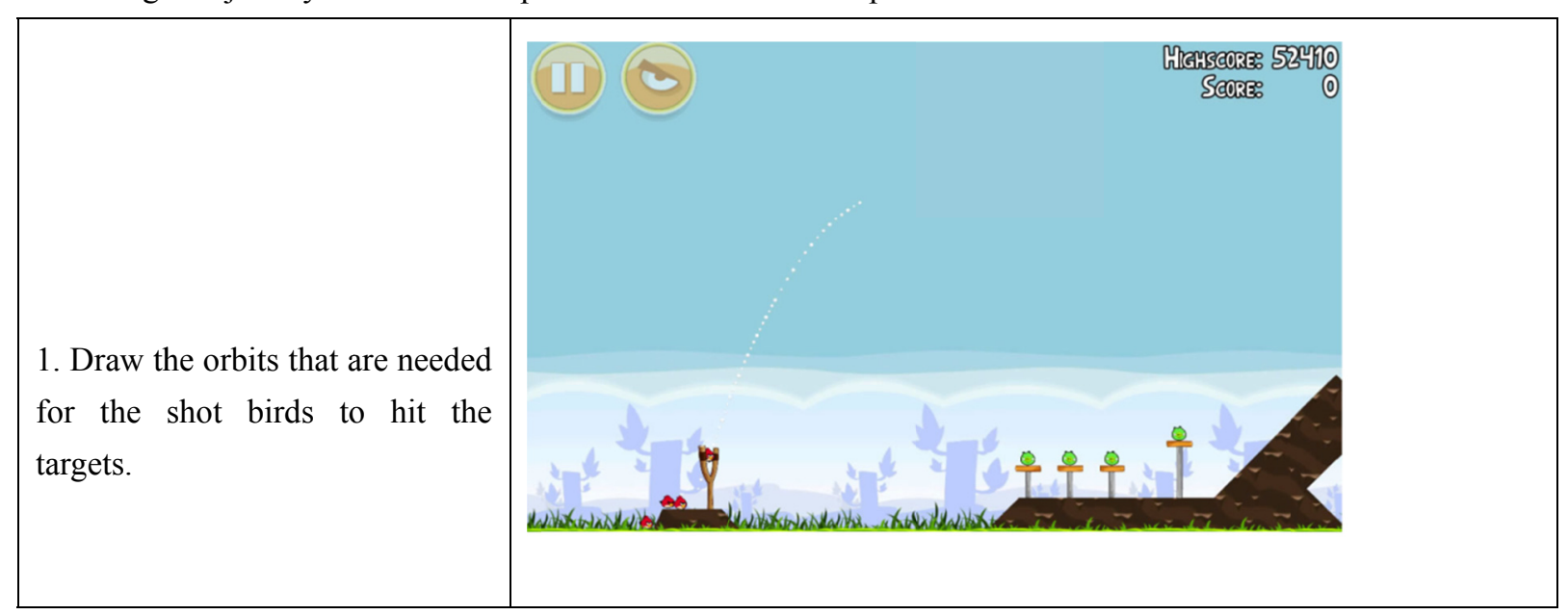




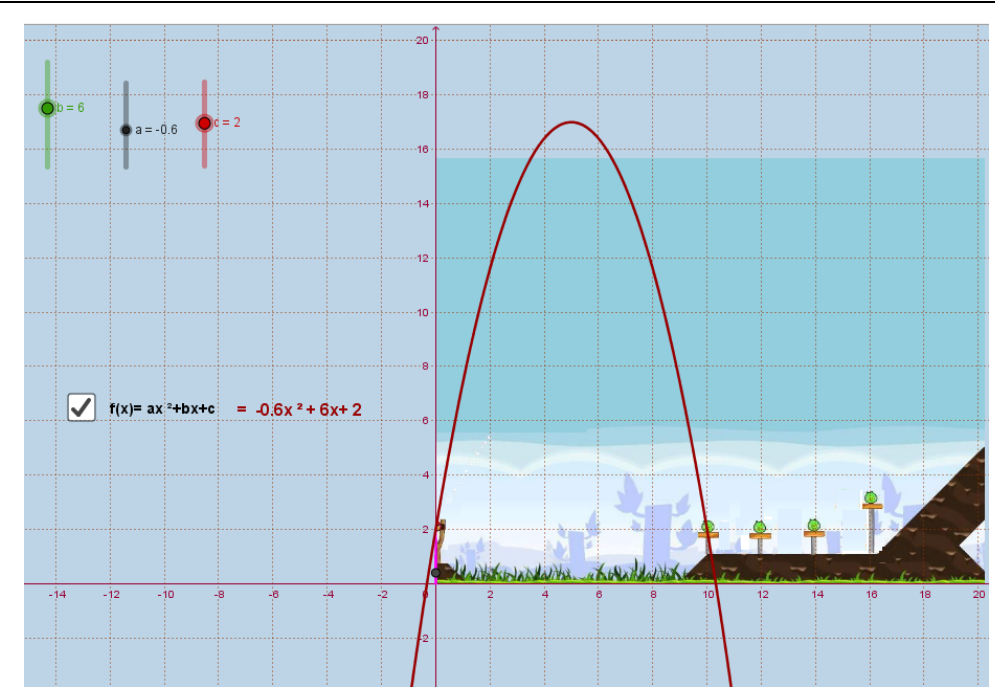

2. Please examine the application.

Move the $\mathrm{a}, \mathrm{b}$, and $\mathrm{c}$ slides to create parabolic graphs that must be followed by the angry birds thrown at the $\mathrm{E}(0.2)$ point to hit the pigs at the target.

Fill in the table

\begin{tabular}{|l|l|l|l|l|l|}
\hline Targets & value of "a" & value of "b" & value of "c" & $\begin{array}{l}\text { Coordinates of the maximum } \\
\text { point reached by the angry bird }\end{array}$ & $\begin{array}{l}\text { Parabola } \\
\text { equation }\end{array}$ \\
\hline 1 st target & & & & & \\
\hline 2 st target & & & & & \\
\hline 3 st target & & & & & \\
\hline 4 st target & & & & & \\
\hline
\end{tabular}

What effect does the value of a,b,c have on the graph of parabola?

\section{Copyrights}

Copyright for this article is retained by the author(s), with first publication rights granted to the journal.

This is an open-access article distributed under the terms and conditions of the Creative Commons Attribution license (http://creativecommons.org/licenses/by/4.0/). 